\title{
Siew New Disease Reports \\ First report of bacterial stalk rot of sweet corn caused by Dickeya zeae in Korea
}

\author{
I.-S. Myung ${ }^{1}$, I.H. Jeong ${ }^{1}$, S.Y. Moon ${ }^{1}$, W.G. Kim ${ }^{1}$, S.W. Lee ${ }^{2}$, Y.H. Lee ${ }^{3}$, Y.-K. Lee ${ }^{1}$, H.S. Shim ${ }^{1}$ and D.S. Ra ${ }^{4}$ \\ ${ }^{1}$ Crop Protection, National Academy of Agricultural Science (NAAS), Rural Development Administration (RDA), Suwon \\ 441-707, Korea; ${ }^{2}$ Agricultural Microbiology, NAAS, RDA, Suwon 441-707, Korea; ${ }^{3}$ Knowledge and Information, RDA. Suwon \\ 441-707, Korea; ${ }^{4}$ Agricultural Safety Engineering, NAAS, RDA, Suwon 441-707, Korea
}

*E-mail: ismyung@rda.go.kr

Received: 31 Mar 2010. Published: 17 Sep 2010. Keywords: Zea mays, Pectobacterium chrysanthemi, recA region

Sweet corn (Zea mays) is one of the most important crops in Korea. In Goesan District, Korea in 2007 it was cultivated on 1,178.7 ha and produced 9,725 tonnes (http://www.goesan.go.kr). Bacterial stalk rot of sweet corn (cv. Daehak) was observed at fields in Goesan District in July 2008. The internodes of diseased plants were tan to brown, and soft rot with a foul odour was evident in the inner parts of stems (Fig. 1). The infected plants had collapsed with blighted leaves and easily removable tops. Tissues showing these symptoms and leaf spot lesions were surface-sterilized in $70 \%$ ethanol for one minute; from these six bacterial isolates were obtained on trypticase soy agar (TSA).Colonies were gray-white and slightly raised with smooth margins on nutrient agar. The bacterial isolates exhibited the biochemical characteristics of the family Enterobacteriaceae. They were Gram-negative, oxidase negative, catalase positive, fermentative, rod shaped, motile, and facultatively anaerobic. All isolates were preliminary identified as Pectobacterium chrysanthemi (Biolog similarity index of a range of 0.65 to $0.7348 \mathrm{hr}$ after inoculation) with the Biolog Microbial Identification System, version 4.2 (Biolog Inc. Hayward, CA). Their identities were confirmed by PCR using primers corresponding to pel genes as described by Nassar et al. (1996). A 1,449-bp fragment of 16S rDNA from the six isolates shared $98 \%$ similarity with one of $P$. chrysanthemi $\mathrm{LMG}_{2804^{\mathrm{T}}}$ in the GenBank database (Accession No. Z96093). The recA region was partially sequenced to aid in identification of two isolates, BC2879 and BC2880, using PCR primers reported by Parkinson et al. (2009). A 481-bp fragment was compared with sequences available in the GenBank database. The isolates clustered with Dickeya zeae PII subclade in a phylogenetic tree generated by the neighbour-joining method in the MEGA software, Version 4.1 (Fig. 2) (Tamura et al., 2007). The recA sequence from the isolates had distance indices of $0.002,0.045$, and 0.154 as determined by the Jukes-Cantor model, with sequences of strains of D. zeae NCPPB 1863 (PII subclade) (FJ217086), D. zeae $\mathrm{NCPPB}^{2538^{\mathrm{T}}}$ (PI subclade) (FJ216967), and D. chrysanthemi $\mathrm{NCPPB} 42^{\mathrm{T}}$ (FJ216968), respectively. On the basis of the recA sequence, the isolates were identified as D. zeae. Nucleotide sequence data are available under the following accession numbers: FJ571651, GQ461741, GQ461742 GQ461743, GQ461744, and GQ461745 for 16S rDNA of isolates BC2877, BC2878, BC2879, BC2880, BC2881 and BC2882, respectively; and HM852143, and HM852144 for
recA of isolates BC2879 and 2880, respectively.

Koch's postulates were completed with inoculation of four-week-old intact sweet corn plants of cv. Danoksusu (three plants per isolate) with $100 \mu \mathrm{l}$ of cell suspensions containing $10^{8} \mathrm{cfu} / \mathrm{ml}$. Plants were inoculated after a pinprick at the base of an internode of the stem and then incubated in a greenhouse at $28^{\circ} \mathrm{C}$ and at $80 \%$ relative humidity. All isolates induced stem infection and leaf blight similar to symptoms observed in natural infections two weeks after inoculation (Fig. 3). The bacterium was re-isolated from symptomatic stems of sweet corn plants. No symptoms were noted on plants inoculated with sterilized distilled water. To our knowledge, this is the first report of bacterial stalk rot of sweet corn caused by $D$. zeae in Korea. Similar disease symptoms in corn had been reported in different countries (Boewe, 1949; Reifschneider \& Lopes, 1982). Further spread of the pathogen is expected to have a high economic impact in sweet corn production in Korea.

\section{Acknowledgements}

The study was supported by Agenda 7-28 of the Rural Development Administration in Korea.

\section{References}

Boewe GH, 1949. Bacterial stalk rot of corn in Illinois. Plant Disease Reporter 33, 342-343

Nassar AA, Darrasse A, Lemattre M, Kotoujansky A, Dervin C, Vedel R, Bertheau Y, 1996. Characterization of Erwinia chrysanthemi by pectinolytic isozyme polymorphism and restriction fragment length polymorphism analysis of PCR-amplified fragment of pel genes. Applied and Environmental Microbiology 62, 2228-2235.

Reifschneider FJB, Lopes CA, 1982. Bacterial top and stalk rot of maize in Brazil. Plant Disease , 519-520.

Tamura K, Dudley J, Nei M, Kumar S, 2007. MEGA 4: Molecular Evolutionary Genetics Analysis (MEGA) software version 4.0. Molecular Biology and Evolution 24, 1596-1599. [doi:10.1093/molbev/msm092]

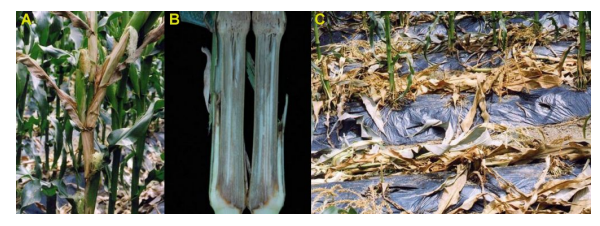

Figure 1

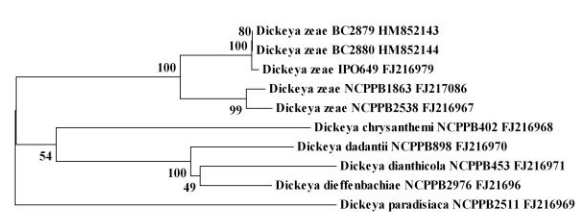

Figure 2

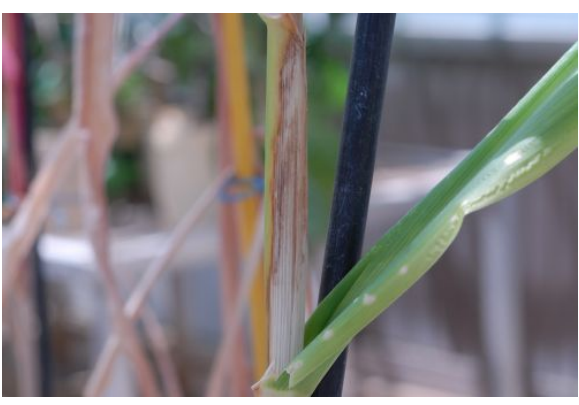

Figure 3

To cite this report: Myung I-, Jeong IH, Moon SY, Kim WG, Lee SW, Lee YH, Lee Y-, Shim HS, Ra DS, 2010. First report of bacterial stalk rot of sweet corn caused by Dickeya zeae in Korea. New Disease Reports 22, 15. [doi:10.5197/j.2044-0588.2010.022.015]

(c) 2010 The Authors

This report was published on-line at www.ndrs.org.uk where high quality versions of the figures can be found. 